\title{
The response of the sexes to nutritional stress
}

\section{By Elsie M. Widdowson, Department of Medicine, University of Cambridge, Cambridge $C B 22 Q Q$}

Nutritional stress will arise when the intake of one or more nutrients is insufficient to meet the requirements. It may also occur when the intake is excessive, but for this to be so the amount absorbed from the intestine must also be more than the body needs, and the individual must be unable to excrete the excess in the urine or to metabolize it. My main concern today is with differences in the response of the sexes to deficiencies and excesses of total energy.

\section{Response of the sexes to undernutrition and starvation}

The female is better able to withstand a shortage of food than the male. I first became aware of this when we were in Germany in 1946, studying the effects of undernutrition on the civilian population. Of the 1400 new adult patients coming to our hunger-oedema out-patient clinic and considered to be sufficiently undernourished to qualify for extra rations, $60 \%$ were men and $40 \%$ women (McCance \& Widdowson, $195 \mathrm{I}$ ). During 1947 some hundreds of children living in various orphanages were weighed and measured and examined clinically as a preliminary to feeding experiments, and it is probable that these children were typical of children in Germany at that time living solely on the rations. They were nearly all short and light for their ages when compared with British or American standards. The older children were worse than the younger ones, and the older boys were always considerably worse than the older girls. When, later, we began to investigate the effects of severe energy and protein deficiencies on pigs and rats, the greater vulnerability of the male was brought home to us even more forcibly. As many of you know, we have undernourished pigs so severely, by giving them very little food from Io d of age, that at the end of I year they weighed $5-6 \mathrm{~kg}$ instead of $150 \mathrm{~kg}$ or more for a well-nourished littermate (McCance \& Widdowson, 1962). Not all the animals we undernourished in this way survived for I year, however, even though we took all the precautions we could about keeping them warm and healthy. Moreover, the survival rate of the two sexes was very different: $87 \%$ of the females were alive at the end of $\mathrm{I}$ year, but only $22 \%$ of the males. The cause that precipitated death was generally infection due to organisms in the lungs and gastrointestinal tract that would not worry a normal pig, but was often lethal to the undernourished ones, particularly the males. Another cause of death was probably heart failure. We found a similar but smaller sex difference in death rate among our protein-deficient pigs: $44 \%$ of the males were alive at the end of $\mathrm{I}$ year, and $83 \%$ of the females. 
We naturally considered reasons for this sex difference in survival. One obvious one is that the period of undernutrition covered the age of puberty, when the demands for nutrients and energy are higher in the male than the female. The same ration of food, therefore, and the maintenance of the animals at a similar bodyweight, is likely to have taken more out of the males than the females. In Germany too, men and women had the same basic rations, and so did boys and girls, and if the individual was not able to supplement them, the rations were more inadequate for men and adolescent boys than for women and girls. But that is not the whole explanation. Nearly 20 years ago we made an experiment on adult and growing rats to compare the effects of complete starvation for $6 \mathrm{~d}$ with those of chronic undernutrition for 6 weeks, and the final body-weight was arranged to be the same (Widdowson \& McCance, 1956). We used males and females, but so concerned were we with comparing the effects of starvation and undernutrition that we paid little attention to the difference in response of the males and females. Table I shows some of the results on the adult rats, presented in a different way from that in the original paper. Both males and females naturally lost weight when they were starved, but in the adult rats the contribution of protein and fat in the body to this loss was quite different in the two sexes. The males lost $16 \%$ of their body protein, the females only $8 \%$. In contrast the males lost $19 \%$ of their body fat compared with $37 \%$ for the females. The livers of the males suffered greater depletion of protein too, and clearly the tissues catabolized to meet the energy requirements during complete starvation were not the same in the two sexes. This is illustrated in another way in Table 2. Of the total energy expended by the males $33 \%$ came from body protein and $67 \%$ from fat. For the females only $8 \%$ came from protein and $92 \%$ from fat. It is true that the females had a higher fat content in their bodies at the outset, 210 compared with $170 \mathrm{~g} / \mathrm{kg}$ for the males, but even after $6 \mathrm{~d}$ starvation the males still had about $160 \mathrm{~g} \mathrm{fat} / \mathrm{kg}$, because fat and weight were lost in approximately the same proportion. The females, on the other hand, reduced the fat content of their bodies from 210 to $160 \mathrm{~g} / \mathrm{kg}$.

Table 1. Percentage of the total amount of protein and fat in the body and of protein in the liver lost by male and female rats during complete starvation

$\begin{array}{lcc} & \text { Males } & \text { Females } \\ \text { Whole body } & & \\ \text { Protein } & 16 & 8 \\ \text { Fat } & 19 & 37 \\ \text { Liver } & & \\ \text { Protein } & 31 & 23\end{array}$

Table 2. Contribution of protein and fat (\%) to the total energy expenditure by rats during complete starvation for $6 d$

$\begin{array}{lcc} & \text { Males } & \text { Females } \\ \text { Protein } & 33 & 8 \\ \text { Fat } & 67 & 92\end{array}$




\section{Vol. 35 Sex differences in response to nutritional variables}

When rapidly growing rats, 9 weeks old, were starved for $6 \mathrm{~d}$ the difference between the sexes was still apparent, but quantitatively smaller. Then males derived $16 \%$ of their energy from protein, females $13 \%$. Thus both age and sex determine the relative proportions of protein and fat utilized to provide energy during complete starvation. The results on adult rats chronically undernourished for 6 weeks were similar to those for animals starved for $6 \mathrm{~d}$. Males derived $34 \%$ of their energy from protein, females $8 \%$.

The difference between the adult males and young, rapidly growing ones is reminiscent of the observations made by McCance \& Strangeways (1954) when they studied the effects of starvation for $3 \mathrm{~d}$ on the breakdown of protein by adult men and newborn male infants. The men, both young and old, derived about $20 \%$ of their energy from protein, the infants $4 \%$. As far as I know all the studies on tissue breakdown during starvation in normal human adults have been made on men. I now suggest that similar studies on women might show a much smaller breakdown of protein during starvation and a proportionally greater breakdown of fat to provide for the demand for energy.

A large loss of protein from the body is metabolically a far more serious matter than loss of fat, and the greater catabolism of protein in males is probably an important reason why they withstand a deficiency of energy less well than females. They are also less able to withstand a shortage of protein. Stephen (I g68) concluded, from studies on the urea cycle enzyme, argininosuccinate lyase (EC 4.3.2. 1 ), in protein deficiency, that the adaptations were more efficient and more extensive in female than in male rats.

The questions we must now try to answer are these. (I) Why do females lose less protein from their bodies than males when they are deprived of food? (2) Why do young growing males lose less protein than adults? Protein metabolism in the body is a dynamic process. Some cells, for example the erythrocytes and the cells of the jejunal mucosa, are constantly being broken down and new ones formed but, more important, the protein inside all the cells of the body is in a constant state of synthesis and breakdown. In some tissues, for example liver, this process takes place more rapidly than in others, for example collagen. Whether synthesis and anabolism or breakdown and catabolism predominates depends on the supply of food and the activity of hormones such as growth hormone (GH) and the androgenic and oestrogenic hormones. Before adolescence, $\mathrm{GH}$ is the most important internal regulator of protein metabolism. It promotes the synthesis of protein from amino acids; anabolism exceeds catabolism and there is a positive nitrogen balance. When the supply of food for a young child or animal is insufficient, or completely lacking, the level of circulating GH in the plasma rises. This is an adaptive mechanism, for it suppresses the secretion of insulin, so that the blood glucose does not fall to a level incompatible with life. At the same time GH exerts its anabolic effect on protein metabolism so that, even when starving, a newborn infant derives almost all its energy from the breakdown of fat. The newborn of other species catabolize very little protein too. The pig for example, which has very little fat, has a plentiful supply of glycogen in its liver and muscles, 
and the oxidation of this glycogen with a small amount of fat provides it with $98 \%$ of its energy during $24 \mathrm{~h}$ without food, so that the breakdown of protein contributes only $2 \%$ to the total (McCance \& Widdowson, 1959).

There is probably little difference between the sexes in the effect of $\mathrm{GH}$ and food on protein metabolism in the young child and animal, and this is in line with the fact that a sex difference in incidence of clinical marasmus and kwashiorkor does not seem to have been reported. It is not until adolescence, when the androgenic and oestrogenic hormones begin to play their part, that differences between the sexes become apparent. Androgens have an additional anabolic effect on protein synthesis, causing increased protein deposition in all parts of the body, but most notably perhaps in skeletal muscle and cartilage. They trigger off synthetic processes which cause structural changes so that particular muscles and bones grow rapidly, and the individual acquires the body form characteristic of the male. For example the shoulder girdle grows particularly fast, and also the pectoral and shoulder muscles. This is true of man, but it is even more striking in the males of other species, for example the bull, the deer and the cat. Muscles and connective tissue concerned with the male reproductive organs also grow rapidly under the influence of androgens.

The oestrogens do not act in conjunction with GH. They do not have a corresponding effect on specific skeletal muscles of the female, and the muscles continue to grow, in a regular fashion, under the influence of GH. Cheek (1968) showed, from measurements of creatinine excretion, that the growth rate of skeletal muscle of girls had no break at the time of puberty, whereas that of boys increased considerably. Oestrogens exert their main effect, moreover, on the growth of smooth muscle in different parts of the reproductive organs, but these contribute little to the body-weight and there is no great increase in nitrogen retention at puberty in girls. Oestrogens do promote the growth of certain bones, in particular those of the pelvis, although expansion of the tissues around them, like that of the breasts, is largely due to the deposition of adipose tissue.

At the time of puberty, therefore, both $\mathrm{GH}$ and the steroid hormones are concerned with protein metabolism and growth, but in the adult GH is no longer active. Androgens do not have the same protein-sparing effect that GH has, in fact the reverse, so in the starving or undernourished adult male, be he man or rat, catabolism exceeds anabolism, and he breaks down a considerably higher proportion of his body protein to meet his energy requirements than the growing baby or rat. He also breaks down more protein than the female. Much less work seems to have been done on the effect of oestrogens on protein metabolism in different nutritional states than on androgens, but it seems reasonable to suppose that oestrogens have a preferential anabolic effect in times of food deprivation, or an undernourished woman would scarcely be able to reproduce-and we know that she can.

\section{Response to rehabilitation}

Fig. I shows the gain in weight of male and female rats undernourished for 8 weeks and then rehabilitated by being given unlimited food (Widdowson, Mavor \& 

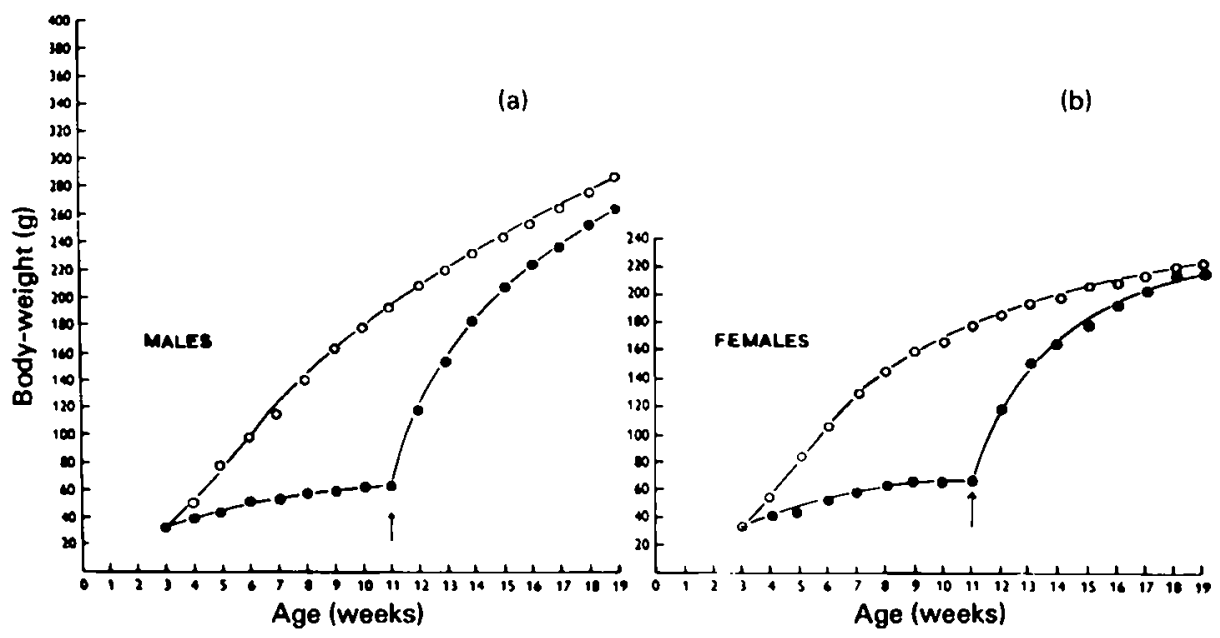

Fig. I. Gain in body-weight of $(a)$ male and $(b)$ female rats during rehabilitation after being undernourished for 8 weeks. - , Undernourished, then rehabilitated; $O-O$, well-nourished controls; $\uparrow$, start of rehabilitation.

McCance, 1964). Both sexes responded by gaining weight rapidly, but the males did not achieve the weight of littermates that had not been undernourished. The females very nearly did. These results tell us nothing about the composition of the weight gained, how much is fat and how much lean tissue, and whether the males and females are fatter or leaner than they would have been had they not been undernourished. We are investigating this at the present time. Our severely undernourished pigs also gained weight very rapidly after 1,2 or even 3 years of severe undernutrition (Lister \& McCance, 1967; Widdowson, 1974), but they never grew to the size of the well-nourished littermates, and the longer the period of undernutrition the less complete the catch-up growth becomes. The same is true of rats (McCay, Maynard, Sperling \& Barnes, 1939; McCay, Sperling \& Barnes, 1943; Widdowson \& McCance, 1963). Because of the vulnerability of male pigs to undernutrition it is only females that we have succeeded in bringing through 2 or 3 years of such severe deprivation, and these females, when rehabilitated, certainly become extremely fat. The longer the period of deprivation the fatter they become.

\section{Response of the sexes to overnutrition}

Surveys of the incidence of obesity in various parts of the world have shown that about twice as many women as men are $20 \%$ or more overweight. Is this because our standards for women's weight are too low, because women's appetite control is less exact, or is it because a similar excess of food leads to a greater deposition of fat in the female than in the male? There is no doubt that at the time of puberty females of human and animal species normally deposit considerably more fat in their bodies than males, suggesting that one of the functions of the oestrogenic hormones is to promote the deposition of fat. This is borne out by the fact that 
during pregnancy even more fat is deposited in the mother's body: Hytten \& Leitch (197I) suggest about $4 \mathrm{~kg}$ for a woman, which is more than the baby weighs.

What then happens to the excess energy taken by men in the form of food? Do they burn it off by raising their metabolic rate after each meal to a greater extent than women? There is no evidence from the studies of Strong, Shirling \& Passmore ( 1967 ), Miller \& Mumford (1967) and Miller, Mumford \& Stock (r967) that men responded differently in any way from women to an excessive intake of energy, but this was not specifically sought. Men and women certainly react differently to excess energy in the form of heat just as they do to a deficiency in the form of cold. In the same hot environment men begin sweating sooner than women and so keep their body temperature down. Women store heat, and their body temperature rises before they begin sweating (Bittel \& Henane, 1975). In the same cool environment men begin to call upon their reserves of energy by shivering sooner than women. Women conserve heat and maintain their body temperature by vasoconstricting their peripheral blood vessels (Hardy \& Du Bois, 1940). The whole problem of conservation and disposal of heat and energy is still open to further investigation, and a look by nutritionists as well as physiologists at differences between the sexes might prove profitable.

\section{REFERENCES}

Bittel, J. \& Henane, R. (1975). J. Physiol., Lond. 250, 475.

Cheek, D. B. (1968). Human Growth. Philadelphia: Lea \& Febiger.

Hardy, J. D. \& Du Bois, E. F. (1940). Proc. natn. Acad. Sci. U.S.A. 26, 389.

Hytten, F. E. \& Leitch, I. (1971). The Physiology of Human Pregnancy, and ed. Oxford: Blackwell Scientific Publications.

Lister, D. \& McCance, R. A. (1967). Br. J. Nutr. $21,787$.

McCance, R. A. \& Strangeways, W. M. B. (1954). Br. F. Nutr. 8, 21.

McCance, R. A. \& Widdowson, E. M. (1951). Spec. Rep. Ser. med. Res. Coun. no. 275.

McCance, R. A. \& Widdowson, E. M. (1959). Y. Physiol., Lond. 147, 124.

McCance, R. A. \& Widdowson, E. M. (1962). Proc. R. Soc. B 156, 326.

McCay, C. M., Maynard, L. A., Sperling, G. \& Barnes, L. L. (1939). F. Nutr. 18, 1.

McCay, C. M., Sperling, G. \& Barnes, L. L. (1943). Archs Biochem. 2, 469.

Miller, D. S. \& Mumford, P. (1967). Am. J. clin. Nutr. $20,1212$.

Miller, D. S., Mumford, P. \& Stock, M. J. (1967). Am. J. clin. Nutr. 20, 1223.

Stephen, J. M. L. (1968). Br. J. Nutr. 22, 153 .

Strong, J. A., Shirling, D. \& Passmore, R. (1967). Br. 7. Nutr. 21, 909.

Widdowson, E. M. (1974). In Nutrition and Malnutrition: Identification and Measurement, p. I65 [A. F. Roche and F. Falkner, editors]. New York: Plenum Press.

Widdowson, E. M. \& McCance, R. A. (1956). Br. F. Nutr. 10, 363.

Widdowson, E. M. \& McCance, R. A. (1963). Proc. R. Soc. B 158, 329.

Widdowson, E. M., Mavor, W. O. \& McCance, R. A. (I964). F. Endocr. 29, I19. 